\title{
The use of libraries and information centres by agricultural researchers and extension workers in Zimbabwe
}

\author{
Tinashe Mugwisi ${ }^{1}$ \\ mugwit@unisa.ac.za \\ ORCID Id.: http://orcid.org/0000-0001-9307-3927
}

\begin{abstract}
Received: 13 February 2014
\end{abstract}
Accepted: 24 June 2014

\begin{abstract}
Access to information through libraries and information centres, among others, enhances the timeliness and quality of such information. This study sought to establish how agricultural researchers and extension workers in Zimbabwe utilise libraries and information centres in the course of their work. Data was collected through a questionnaire which was distributed to agricultural researchers and extension workers. Data was analysed using SPSS and content analysis. The results showed that the majority of researchers have access to libraries within the Ministry of Agriculture, Mechanisation and Irrigation Development's research and extension divisions, while the majority of extension workers do not have access to these library services. The absence of access to libraries confirms why the majority of extension workers consult print sources and departmental collections first, and their preference for using publications in disseminating information to farmers. The respondents also utilise alternative sources of information, including circulars from the Ministry of Agriculture 's head office, personal and departmental collections, media sources (newspapers, radio, audio materials), and other libraries. University libraries are the most-utilised alternative choice. Libraries in non-governmental organisations (NGOs) were also mentioned as alternatives. The libraries of the Ministry are generally not adequately equipped to support the information needs of researchers and extension workers and, although the Central Library's strength is reflected in the availability of and access to databases, the inability of users to access these resources from other centres or institutes cancels this advantage. The Ministry of Agriculture does not have a "visible policy" regarding the management of information generated by its departments and resources are only concentrated in one locality. The study recommends the allocation of resources, both human and material, and the maximisation of the use of available electronic resources, which are otherwise underutilised.
\end{abstract}

Keywords: Agriculture, research, extension, libraries, Zimbabwe

\section{Introduction and background to the study}

Research generates information, and the extension system disseminates this information to farmers. In turn, local knowledge held by farmers helps researchers understand farmers' problems. This local knowledge can be communicated either directly by the farmers or through extension channels. One of the main challenges affecting the adaption or adoption of new technologies by farmers is lack of information. The absence of a coordinated national Agricultural Knowledge and Information System (AKIS) creates information gaps in agriculture and related environments (Food and Agriculture Organization of the United Nations [FAO] 2000, Rees et al. 2000, Chema, Gilbert \& Roseboom 2003). Agriculture is the dominant sector in Zimbabwe's economy, contributing $20.3 \%$ of the Gross Domestic Product (GDP) and providing income to over 75\% of the population (Muir-Leresche 2006: 99, Global Finance 2013). The specific decline, from a GDP contribution of $23.7 \%$ in 1999 to $14.6 \%$ in 2003, is attributed to the reduction of area planted in relation to crop type (Moyo, Moyo \& Matondi 2004).

According to Ojiambo in Kiplang'at (2004: 2), agricultural technology transfer depends on a holistic agricultural information system that comprises a research subsystem, the extension subsystem, a farmer's subsystem and an information subsystem. A national agriculture information system ensures that information generated by agricultural agencies, institutions and researchers is collated and made available to a wider audience, including farmers, through channels which include the extension systems. Libraries and information centres play an important role in the dissemination of agricultural information. They provide access to information ranging from broad subject coverage to specific disciplines, depending on the intended clientele and institutions that they represent. Libraries and information centres can be found in universities, colleges, and the Ministry of Agriculture, Mechanisation and Irrigation Development and its related research institutes and colleges. The available material formats range from books or print to electronic and web sources and there is a growing trend towards the adoption of electronic information resources, although institutional capacities vary.

1. Tinashe Mugwisi is a Post-Doctoral Fellow in the Department of Information Science, University of South Africa. 
According to Dulle et al. (2001: 190), access to timely and relevant information and the proper recording and organisation of information are key issues in the effectiveness of any research system. Their study revealed that the majority of agricultural researchers felt that information provision by many agricultural libraries in Tanzania was inadequate. Among the challenges faced by libraries at that time were: lack of comprehensive journal collections; lack of up-to-date information; lack of information technology facilities (internet, CD-ROMs); inadequate funding; poor information access skills; and book mutilation. Dulle et al. (2001: 190) found that researchers resorted to libraries outside the country or international organisations like The International Council for Research in Agroforestry (ICRAF) to address their information needs due to poor library collections.

\section{Problem statement}

Agriculture extension plays an important role in the technology transfer process. Kiplang'at (1999: 115) argues that the key to increased agricultural production ultimately lies in the nation's ability to disseminate relevant information to the farming community; facilitate the effective adoption of new production techniques; apply agricultural inputs; and make decisions on markets, prices and methods of conserving water, soil and vegetable resources.

According to Eicher and Swanson in Pazvakavambwa and Hakutangwi (2006: 217),

agricultural extension is the process of transferring agricultural information and technology to farmers for use in production and marketing decisions and similarly transferring information from farmers to researchers.

This process is further enhanced when there is a strong and clearly identifiable research and extension system in place. Although these ideas seem sensible now, Pazvakavambwa and Hakutangwi (2006: 228) observed that this has not always been the case: for a long time the extension worker was a mere visitor at research stations while the researcher remained unfamiliar with the farming realities on the ground. Swanson (1997: 171) likewise observed that the lack of close working rapport "between national agricultural research and extension organisations, and with different categories of farmer organisations, is one of the difficult institutional problems confronting ministries of agriculture in many developing countries".

The agricultural extension system in Zimbabwe is experiencing challenges largely to do with staffing and inadequate access to information by extension staff in dealing with farmers' information needs. There is concern about the preparedness of extension workers to deal with challenges on the ground. An example cited in the Herald ("Arex battles to fill"... 2006) highlights the challenges faced by an extension worker with general farming knowledge who is deployed to work in an area where there is a need for expert advice in soya bean production. There is also concern about how lack of technical information on farming affects extension officers and leads to their failure to attend to farmers' problems in time ("Farmers struggle to access"... 2006). The land reform programme has also seen an exponential growth in the number of farmers, placing further demands on information on various farming practices by farmers, which research and extension services must respond to positively. Such are the characteristics of the research and extension systems in Zimbabwe and the problems affecting the farmers.

\section{Purpose of the study}

The purpose of this study was to investigate access and utilisation of libraries and information centres by agricultural researchers and extension workers within the Ministry of Agriculture, Mechanisation and Irrigation Development's research and extension divisions, and research institutes, given the existing challenges by extension workers to address farmers' needs. In particular, the study sought to answer the following research questions:

1. What is the level of access to libraries and information centres by agricultural researchers and extension workers?

2. What are the information seeking patterns of researchers and extension workers in terms of purpose, sources used and preferences?

3. What are the challenges faced by researchers and extension workers in their utilisation of libraries and information centres for work and related purposes?

4. What recommendations can be made to improve on the status quo?

\section{Methodology}

The study utilised both qualitative and quantitative techniques. Data was collected through a questionnaire distributed to researchers and extension workers. The study used a questionnaire with structured and open-ended questions and enabled respondents to provide additional remarks, thus generating both quantitative and qualitative responses. Extension workers were drawn from eight provinces, which yielded eight provincial extension officers and sixty district extension officers. Further district extension officers from fourteen districts were selected using random sampling to provide field experiences, although this category was extensively investigated in Mashonaland Central Province. The study also targeted the ninety-one subject matter specialists in the eight provinces, including those stationed at the head office. The categories of Agricultural Extension Officers, Agricultural Extension Supervisors and AGRITEX workers were drawn from Mashonaland Central Province to create a representative sample of agro-ecological regions II-V. Due to the large number of extension workers involved at the ward level, the study did not investigate this category at the national 
level, but restricted the investigation to Mashonaland Central Province which was considered representative in terms of agricultural practices. Purposive sampling was applied to Mashonaland Central Province, with all seven districts investigated. Random sampling was then conducted for the different wards.

A total of 111 questionnaires were distributed to researchers and sixty were returned which achieved a return rate of $54 \%$. However, errors were identified in four of the questionnaires and they were discarded. Usable returns therefore amounted to fifty-six. The total target population for extension workers in this study was 318. Two directors (Technical and Field) and one deputy director were interviewed and were not required to complete the questionnaire. A total of 172 questionnaires were completed by extension workers, achieving a return rate of $54 \%$.

\section{Results}

Results are presented below. Each sub-heading pertains to a question asked to participants.

\subsection{Access to a library or information resource centre}

Respondents were asked whether they had access to a library, information resource centre or information kiosk in their work environment or community. The results indicated that $129(56.6 \%)$ respondents have access, while ninety-nine $(43.7 \%)$ do not have access to library or information facilities. Those who have access totalled seventy-eight $(45.3 \%)$ extension workers and fifty-one $(91.1 \%)$ researchers, while ninety-four extension workers $(54.7 \%)$ and five researchers (8.9\%) do not have access.

All the libraries are located within the research institutes, either as part of the main administration buildings or as a separate building, and this makes the libraries more accessible to users within the institutes. The libraries' sizes are relative to other units within the buildings, although space is considered inadequate both in terms of shelves and seating space.

\subsubsection{Staffing and membership}

The Ministry of Agriculture's research institutes face a critical staff challenge and only the Central Library has a librarian, while the remaining research institutes are staffed by a library assistant, an executive assistant and research officers. The libraries' opening hours are in keeping with normal working hours and, where there are no library staff in charge, opening hours are determined by the availability of the research officers in charge, or their equivalent. Membership is open to all ministry employees (including those from other government departments), students, researchers, and members of the public on request.

\subsection{Information seeking patterns}

Overall, the majority of respondents $(172 ; 75.4 \%)$ indicated that they require information when assisting farmers; the smallest number of respondents (twenty-four; 10.5\%) require information when assisting researchers, as summarised in Table 1 below.

Table 1 Information seeking patterns

\begin{tabular}{|c|c|c|c|c|c|c|}
\hline \multirow{2}{*}{$\begin{array}{l}\text { Information seeking purposes } \\
\text { To conduct research }\end{array}$} & \multicolumn{2}{|c|}{$\begin{array}{c}\text { Agricultural } \\
\text { Extension Worker } \\
\mathrm{N}=172\end{array}$} & \multicolumn{2}{|c|}{$\begin{array}{l}\text { Agricultural } \\
\text { Researcher } \\
\quad N=56\end{array}$} & \multicolumn{2}{|c|}{$\begin{array}{c}\text { Total } \\
\mathrm{N}=228\end{array}$} \\
\hline & 95 & $55.2 \%$ & 44 & $78.6 \%$ & 139 & $61 \%$ \\
\hline General awareness & 73 & $42.4 \%$ & 13 & $23.2 \%$ & 86 & $37.7 \%$ \\
\hline When assisting extension workers & 61 & $35.5 \%$ & 19 & $33.9 \%$ & 80 & $35.1 \%$ \\
\hline When assisting farmers & 149 & $86.6 \%$ & 23 & $41.1 \%$ & 172 & $75.4 \%$ \\
\hline When assisting researchers & 18 & $10.5 \%$ & 6 & $10.7 \%$ & 24 & $10.5 \%$ \\
\hline
\end{tabular}

Multiple responses are represented in the table.

\subsubsection{Primary source when in need of information}

Respondents were asked to indicate whom they consult first when they need information. The majority (fifty-seven; 25\%) indicated that they first consult the internet, followed by departmental collections (fifty-four; $23.7 \%$ ), colleagues (forty-six; 20.2\%), personal collections (thirty-eight; 16.7\%), and the library (thirty; 13.2\%). Most extension workers (forty-eight; $27.9 \%$ ) consult departmental collections, while the majority of researchers (twenty-eight; 50\%) consult the internet. These numbers are shown in Table 2.

\subsubsection{Print and electronic sources}

Respondents were asked to indicate what they would consult or choose first between print and electronic sources when in need of information. Print sources were selected by an overwhelming $175(76.8 \%)$ of the respondents, while fifty-three $(23.2 \%)$ indicated that they would use electronic sources first. 
The responses of extension workers indicated that 156 (90.7\%) prefer print sources, with only sixteen (9.3\%) mentioning electronic sources. Responses from researchers showed that the majority (thirty-seven; 66.1\%) prefer electronic sources, with nineteen (33.9\%) mentioning print sources.

Table 2 Primary source when in need of information

\begin{tabular}{lcccc}
\hline $\begin{array}{l}\text { Who or what do you consult first } \\
\text { when in need of information? }\end{array}$ & $\begin{array}{c}\text { Agricultural Extension } \\
\text { Worker }\end{array}$ & \multicolumn{2}{c}{ Agricultural Researcher } \\
\hline Library & 24 & $14 \%$ & 6 & $10.7 \%$ \\
Internet & 29 & $16 \%$ & 28 & $50.0 \%$ \\
Colleagues & 37 & $21 \%$ & 9 & $16.1 \%$ \\
Personal collection & 31 & $18 \%$ & 7 & $12.5 \%$ \\
Departmental collection & 48 & $27.9 \%$ & 6 & $10.7 \%$ \\
Workshops \& seminars & 3 & $1.7 \%$ & - & - \\
Total & $\mathbf{1 7 2}$ & $\mathbf{1 0 0 \%}$ & $\mathbf{5 6}$ & $\mathbf{1 0 0 \%}$ \\
\hline
\end{tabular}

\subsubsection{Importance of information sources in keeping up-to-date}

Respondents were asked to indicate the importance of different sources of information in keeping up-to-date with scientific developments in their related fields. Their responses revealed that technical reports are considered to be very important by $164(71.9 \%)$ respondents, specifically $126(73 \%)$ extension workers and thirty-eight (67.9\%) researchers. Journals are considered to be "important" or "very important" by researchers, with only one (1.8\%) not believing this to be the case. Consulting knowledgeable persons in the field or the supervisor are considered to be "important" or "very important" by $164(95.3 \%)$ of the extension workers. Table 3 below provides a detailed analysis of the importance of certain information sources.

Table 3 Importance of information sources in keeping up-to-date

\begin{tabular}{|c|c|c|c|c|c|c|c|}
\hline \multirow{2}{*}{$\begin{array}{l}\text { Information Resource } \\
\text { Journal articles }\end{array}$} & \multirow{2}{*}{$\begin{array}{c}\text { Relative Importance } \\
\text { Very important }\end{array}$} & \multicolumn{2}{|c|}{$\begin{array}{c}\text { Agricultural } \\
\text { extension worker } \\
N=172\end{array}$} & \multicolumn{2}{|c|}{$\begin{array}{l}\text { Agricultural } \\
\text { Researcher } \\
\mathrm{N}=56\end{array}$} & \multicolumn{2}{|c|}{$\begin{array}{l}\text { Total } \\
\mathrm{N}=228\end{array}$} \\
\hline & & 51 & $29.7 \%$ & 38 & $69.7 \%$ & 89 & $39 \%$ \\
\hline & Important & 92 & $53.4 \%$ & 17 & $30.4 \%$ & 109 & $47.8 \%$ \\
\hline & Not important & 29 & $16.9 \%$ & 1 & $1.8 \%$ & 30 & $13.2 \%$ \\
\hline \multirow[t]{3}{*}{ Review articles } & Very important & 43 & $25 \%$ & 24 & $42.9 \%$ & 67 & $29.4 \%$ \\
\hline & Important & 102 & $59.3 \%$ & 31 & $55.4 \%$ & 133 & $58.3 \%$ \\
\hline & Not important & 27 & $15.7 \%$ & 1 & $1.8 \%$ & 28 & $12.3 \%$ \\
\hline \multirow{3}{*}{$\begin{array}{l}\text { Conference abstract and } \\
\text { proceedings }\end{array}$} & Very important & 41 & $23.8 \%$ & 22 & $39.3 \%$ & 63 & $27.6 \%$ \\
\hline & Important & 85 & $49.4 \%$ & 31 & $55.4 \%$ & 116 & $50.9 \%$ \\
\hline & Not important & 46 & $26.7 \%$ & 3 & $5.4 \%$ & 49 & $21.5 \%$ \\
\hline \multirow[t]{3}{*}{ Books } & Very important & 123 & $71.5 \%$ & 24 & $42.9 \%$ & 147 & $64.5 \%$ \\
\hline & Important & 43 & $25 \%$ & 29 & $51.8 \%$ & 72 & $31.6 \%$ \\
\hline & Not important & 6 & $3.5 \%$ & 3 & $5.4 \%$ & 9 & $3.9 \%$ \\
\hline \multirow[t]{3}{*}{ Professional meetings/ workshops } & Very important & 116 & $67.4 \%$ & 30 & $53.6 \%$ & 146 & $64 \%$ \\
\hline & Important & 51 & $29.7 \%$ & 24 & $42.9 \%$ & 75 & $32.9 \%$ \\
\hline & Not important & 5 & $2.9 \%$ & 2 & $3.6 \%$ & 7 & $3.1 \%$ \\
\hline \multirow{3}{*}{$\begin{array}{l}\text { Sources of contents / contents } \\
\text { pages }\end{array}$} & Very important & 38 & $22.1 \%$ & 6 & $10.7 \%$ & 44 & $19.3 \%$ \\
\hline & Important & 93 & $54.1 \%$ & 35 & $62.5 \%$ & 128 & $56.1 \%$ \\
\hline & Not important & 41 & $23.8 \%$ & 15 & $26.8 \%$ & 56 & $24.6 \%$ \\
\hline \multirow[t]{3}{*}{ Indexing and abstracting journals } & Very important & 29 & $16.9 \%$ & 16 & $28.6 \%$ & 45 & $19.7 \%$ \\
\hline & Important & 89 & $51.7 \%$ & 34 & $60.7 \%$ & 123 & $53.9 \%$ \\
\hline & Not important & 54 & $31.4 \%$ & 6 & $10.7 \%$ & 60 & $26.3 \%$ \\
\hline
\end{tabular}

Multiple responses are represented in the table. 


\begin{tabular}{|c|c|c|c|c|c|c|c|}
\hline \multirow{2}{*}{$\begin{array}{l}\text { Information Resource } \\
\text { Research reports/ patents }\end{array}$} & \multirow{2}{*}{$\begin{array}{c}\text { Relative Importance } \\
\text { Very important }\end{array}$} & \multicolumn{2}{|c|}{$\begin{array}{c}\text { Agricultural } \\
\text { extension worker } \\
N=172\end{array}$} & \multicolumn{2}{|c|}{$\begin{array}{l}\text { Agricultural } \\
\text { Researcher } \\
\mathrm{N}=56\end{array}$} & \multicolumn{2}{|c|}{ Total } \\
\hline & & 85 & $49.4 \%$ & 42 & $75 \%$ & 127 & $55.7 \%$ \\
\hline & Important & 70 & $40.7 \%$ & 13 & $23.2 \%$ & 83 & $36.4 \%$ \\
\hline & Not important & 17 & $9.9 \%$ & 1 & $1.8 \%$ & 18 & $7.9 \%$ \\
\hline \multirow[t]{3}{*}{ Technical reports } & Very important & 126 & $73.3 \%$ & 38 & $67.9 \%$ & 164 & $71.9 \%$ \\
\hline & Important & 39 & $22.7 \%$ & 15 & $26.8 \%$ & 54 & $23.2 \%$ \\
\hline & Not important & 7 & $4.1 \%$ & 3 & $5.4 \%$ & 10 & $4.4 \%$ \\
\hline \multirow[t]{3}{*}{ Fact sheets } & Very important & 121 & $70.3 \%$ & 16 & $28.6 \%$ & 137 & $60.1 \%$ \\
\hline & Important & 40 & $23.3 \%$ & 30 & $53.7 \%$ & 70 & $30.7 \%$ \\
\hline & Not important & 11 & $6.4 \%$ & 10 & $17.9 \%$ & 21 & $9.2 \%$ \\
\hline \multirow[t]{3}{*}{ Pamphlets/ leaflets } & Very important & 101 & $58.7 \%$ & 13 & $23.2 \%$ & 114 & $50 \%$ \\
\hline & Important & 62 & $36 \%$ & 34 & $60.7 \%$ & 96 & $42.1 \%$ \\
\hline & Not important & 9 & $5.2 \%$ & 9 & $16.1 \%$ & 18 & $7.9 \%$ \\
\hline \multirow[t]{3}{*}{ Internet sources } & Very important & 87 & $50.6 \%$ & 50 & $89.3 \%$ & 137 & $60.1 \%$ \\
\hline & Important & 46 & $26.7 \%$ & 6 & $10.7 \%$ & 52 & $22.8 \%$ \\
\hline & Not important & 39 & $22.7 \%$ & - & - & 39 & $17.1 \%$ \\
\hline \multirow[t]{3}{*}{ Theses and dissertations } & Very important & 26 & $15.1 \%$ & 22 & $39.3 \%$ & 28 & $21.1 \%$ \\
\hline & Important & 74 & $43 \%$ & 28 & $50 \%$ & 102 & $44.7 \%$ \\
\hline & Not important & 72 & $41.9 \%$ & 6 & $10.7 \%$ & 78 & $34.2 \%$ \\
\hline \multirow[t]{3}{*}{ Newsletters } & Very important & 51 & $29.7 \%$ & 16 & $28.6 \%$ & 67 & $29.4 \%$ \\
\hline & Important & 98 & $57 \%$ & 34 & $60.7 \%$ & 132 & $57.9 \%$ \\
\hline & Not important & 23 & $13.4 \%$ & 6 & $10.7 \%$ & 29 & $12.7 \%$ \\
\hline \multirow[t]{3}{*}{ Library catalogue } & Very important & 49 & $28.5 \%$ & 7 & $12.5 \%$ & 56 & $24.6 \%$ \\
\hline & Important & 80 & $46.5 \%$ & 36 & $64.3 \%$ & 116 & $50.9 \%$ \\
\hline & Not important & 43 & $25 \%$ & 13 & $23.2 \%$ & 56 & $24.6 \%$ \\
\hline \multirow{3}{*}{$\begin{array}{l}\text { Face to face conversations/ } \\
\text { discussions }\end{array}$} & Very important & 100 & $58.1 \%$ & 24 & $42.9 \%$ & 124 & $54.4 \%$ \\
\hline & Important & 59 & $34.3 \%$ & 31 & $55.4 \%$ & 90 & $39.5 \%$ \\
\hline & Not important & 13 & $7.6 \%$ & 1 & $1.8 \%$ & 14 & $6.1 \%$ \\
\hline \multirow[t]{3}{*}{ Email/ list serve/ discussion forums } & Very important & 45 & $26.2 \%$ & 19 & $33.9 \%$ & 64 & $28.1 \%$ \\
\hline & Important & 81 & $47.1 \%$ & 30 & $53.6 \%$ & 111 & $48.7 \%$ \\
\hline & Not important & 46 & $26.7 \%$ & 7 & $12.5 \%$ & 53 & $23.2 \%$ \\
\hline \multirow[t]{3}{*}{ Librarian/ library staff } & Very important & 38 & $22.1 \%$ & 11 & $19.6 \%$ & 49 & $21.5 \%$ \\
\hline & Important & 82 & $47.7 \%$ & 25 & $44.6 \%$ & 107 & $46.9 \%$ \\
\hline & Not important & 52 & $30.2 \%$ & 20 & $35.7 \%$ & 72 & $31.6 \%$ \\
\hline \multirow{3}{*}{$\begin{array}{l}\text { Consult knowledgeable person in } \\
\text { the field/ supervisor }\end{array}$} & Very important & 101 & $58.7 \%$ & 31 & $55.4 \%$ & 132 & $57.9 \%$ \\
\hline & Important & 63 & $36.6 \%$ & 22 & $39.3 \%$ & 85 & $37.3 \%$ \\
\hline & Not important & 8 & $4.7 \%$ & 3 & $5.4 \%$ & 11 & $4.8 \%$ \\
\hline
\end{tabular}

Multiple responses are represented in the table.

\subsubsection{Frequency of use of information sources}

Having identified the importance of information sources, the respondents were asked to indicate how often they consult these sources. Table 4 provides a combined summary of the responses.

The responses indicate that books are the most frequently used information source, with 118 respondents $(51.8 \%)$ indicating they use them very often. The resources that were never used were theses and dissertations (ninety-two respondents; 40.4\%), consulting library staff (eighty-eight; 38.6\%), e-mail/list serve/discussion groups (seventy-six; $33.3 \%$ ) and internet sources (seventy-two; $31.6 \%$ ). 
Table 4 Frequency of use of information sources

\begin{tabular}{|c|c|c|c|c|c|c|c|c|}
\hline \multirow{3}{*}{$\begin{array}{l}\text { Information Source } \\
\text { Journal articles }\end{array}$} & \multicolumn{8}{|c|}{$\begin{array}{l}\text { Frequency of access } \\
\text { Extension workers } \mathrm{N}=172 \text { Researchers } \mathrm{N}=56\end{array}$} \\
\hline & \multicolumn{2}{|c|}{ Very often } & \multicolumn{2}{|c|}{ Often } & \multicolumn{2}{|c|}{ Sometimes } & \multicolumn{2}{|c|}{ Never } \\
\hline & 38 & $16.7 \%$ & 49 & $21.5 \%$ & 117 & $51.3 \%$ & 24 & $10.5 \%$ \\
\hline Review articles & 30 & $13.2 \%$ & 54 & $23.7 \%$ & 117 & $51.3 \%$ & 27 & $11.8 \%$ \\
\hline Conference abstracts \& proceedings & 16 & $7.0 \%$ & 60 & $26.3 \%$ & 102 & $44.7 \%$ & 50 & $21.9 \%$ \\
\hline Books & 118 & $51.8 \%$ & 78 & $34.2 \%$ & 29 & $12.7 \%$ & 3 & $1.3 \%$ \\
\hline Professional meetings/workshops & 63 & $27.6 \%$ & 86 & $37.7 \%$ & 76 & $33.3 \%$ & 3 & $1.3 \%$ \\
\hline Sources of contents (content pages) & 29 & $12.7 \%$ & 47 & $20.6 \%$ & 105 & $46.1 \%$ & 47 & $20.6 \%$ \\
\hline Indexing and abstracting journals & 13 & $5.7 \%$ & 47 & $20.6 \%$ & 95 & $41.7 \%$ & 73 & $32 \%$ \\
\hline Research reports/patents & 44 & $19.3 \%$ & 77 & $33.8 \%$ & 82 & $36 \%$ & 25 & $11 \%$ \\
\hline Technical reports & 85 & $37.3 \%$ & 87 & $38.2 \%$ & 46 & $20.2 \%$ & 10 & $4.4 \%$ \\
\hline Fact sheets & 74 & $32.5 \%$ & 88 & $38.6 \%$ & 51 & $22.4 \%$ & 15 & $6.6 \%$ \\
\hline Pamphlets/leaflets & 72 & $31.6 \%$ & 86 & $37.2 \%$ & 51 & $22.4 \%$ & 19 & $8.3 \%$ \\
\hline Internet sources & 76 & $33.3 \%$ & 32 & $14 \%$ & 48 & $21.1 \%$ & 72 & $31.6 \%$ \\
\hline Thesis and dissertations & 17 & $7.5 \%$ & 48 & $21.1 \%$ & 71 & $31.1 \%$ & 92 & $40.4 \%$ \\
\hline Newsletters & 32 & $14 \%$ & 62 & $27.2 \%$ & 106 & $46.5 \%$ & 28 & $12.3 \%$ \\
\hline Library catalogue & 15 & $6.6 \%$ & 47 & $20.6 \%$ & 100 & $43.9 \%$ & 66 & $28.9 \%$ \\
\hline $\begin{array}{l}\text { Face-to-face conversations/ discussions } \\
\text { with colleagues }\end{array}$ & 100 & $43.9 \%$ & 72 & $31.6 \%$ & 43 & $18.9 \%$ & 13 & $5.7 \%$ \\
\hline Email/list serve/discussion forums & 29 & $12.7 \%$ & 42 & $18.4 \%$ & 81 & $35.5 \%$ & 76 & $33.3 \%$ \\
\hline Librarian/library staff & 15 & $6.6 \%$ & 32 & $14 \%$ & 93 & $40.8 \%$ & 88 & $38.6 \%$ \\
\hline $\begin{array}{l}\text { Consult knowledgeable person in the } \\
\text { field/supervisor }\end{array}$ & 96 & $42.1 \%$ & 74 & $32.5 \%$ & 46 & $20.2 \%$ & 12 & $5.3 \%$ \\
\hline
\end{tabular}

Multiple responses are represented in the table.

\subsubsection{Awareness of less-recent books and journals}

This question sought to highlight the significance of older books and journal articles by asking respondents to indicate how they became aware of older sources and the role they expect library staff to play in making their patrons aware of older sources. Citations at the end of journal articles were mentioned by the majority of respondents (142; $64 \%)$, followed by citations at the end of book chapters (132; 59.5\%), browsing older volumes $(131 ; 59 \%)$, and library staff $(161 ; 72.5 \%)$.

\subsubsection{Journal titles familiar to respondents}

This question aimed to establish the respondents' familiarity with general or specific journal titles in their subject areas. Respondents were able to indicate titles covering various aspects of agriculture. the New Farmer, Zimbabwe Journal of Agricultural Research, Kirkia, Zimbabwe Commercial Farmers Union magazine, and Mirimi/Umlimi were among the local publications cited. International journals also featured; examples include: Acta Horticulture (two respondents; 0.9\%), African Journal of Range Management (four; 1.8\%), Zimbabwe Journal of Agriculture (four; 1.8\%), Farmers Weekly (five; 2.2\%), New Farmer (twenty-three; 10.1\%), Canadian Journal of Soil Science (two; 0.9\%), and Journal of Ecology (three; $1.3 \%)$.

\subsection{Frequency of visits to the library or information resource centre}

The majority of respondents (sixty-eight; $29.8 \%$ ) use the facilities monthly, with twenty-seven (11.8\%) using the facilities weekly. Table 5 provides a summary of the responses.

Table 5 indicates similar trends in the responses of researchers and extension workers. For example, monthly visits were mentioned by the majority of both extension workers (forty-three; $25 \%$ ) and researchers (twenty-five; $44.6 \%$ ), while ninety-nine respondents (43.4\%) did not answer this question of which ninety-four (54.7\%) were extension workers. 
Table 5 Frequency of visits to the library or information resource centre (Extension workers $\mathrm{N}=172$ and Researchers $\mathrm{N}=56$ )

\begin{tabular}{lcccccc}
\hline $\begin{array}{c}\text { Frequency of visits to } \\
\text { library/information } \\
\text { resource centre }\end{array}$ & $\begin{array}{c}\text { Agricultural Extension } \\
\text { workers }\end{array}$ & Agricultural Researchers & Total \\
\hline Daily & 11 & $6.4 \%$ & 8 & $14.3 \%$ & $\mathbf{1 9}$ & $\mathbf{8 . 3 \%}$ \\
Weekly & 14 & $8.1 \%$ & 13 & $23.2 \%$ & $\mathbf{2 7}$ & $\mathbf{1 1 . 8 \%}$ \\
Fortnightly & 10 & $5.8 \%$ & 5 & $9 \%$ & $\mathbf{6 . 6}$ & $\mathbf{1 5}$ \\
Monthly & 43 & $25 \%$ & 25 & $44.6 \%$ & $\mathbf{6 8}$ & $\mathbf{2 9}$ \\
Non-response & 94 & $54.7 \%$ & 5 & $8.9 \%$ & $\mathbf{4 3 . 4 \%}$ \\
\hline
\end{tabular}

\subsection{Alternative information access services}

The next question sought to establish how the respondents who do not have access to a library or information resource centre are able to access information. The question attracted 100 responses, ninety-five from extension workers and five from researchers. The majority of respondents (thirty-six; 15.8\%) indicated that they rely on circulars from the Ministry of Agriculture's head office, specifically thirty-four (19.8\%) extension workers and two (3.6\%) researchers. Departmental and personal collections were mentioned by twenty-nine (12.7\%) respondents, representing twenty-eight extension workers $(16.3 \%)$ and one researcher (1.8\%). Newspapers, radio and audio materials were mentioned by nineteen respondents $(8.3 \%)$ : eighteen extension workers $(10.5 \%)$ and one researcher $(1.8 \%)$. Training materials were mentioned by four $(2.3 \%)$ of the extension workers. Some respondents indicated that they utilise other libraries in town, which must be distinguished from the institutional libraries or community libraries indicated above. This distinction was mentioned by twelve $(5.3 \%)$ respondents: one $(1.8 \%)$ researcher and eleven $(6.4 \%)$ extension workers. The libraries that the respondents visit include university libraries, NGO libraries (including the International Crops Research Institute for the Semi-Arid Tropics [ICRISAT]), high school libraries and public libraries. The Food and Agriculture Organization of the United Nations (FAO) regional library and those of seed companies were also among those mentioned.

\subsection{Type of material sought from the library}

The study sought to establish the type of material respondents access from the libraries. The majority of respondents (thirty-five; $15.3 \%$ ) indicated that they consult books. Journals are second, consulted by a total of thirty-one $(13.5 \%)$ respondents. Table 6 below provides a summary of the results.

Table 6 Type of material sought from the library

\begin{tabular}{lcccccc}
\hline $\begin{array}{c}\text { Type of material } \\
\text { sought/consulted }\end{array}$ & \multicolumn{2}{c}{$\begin{array}{c}\text { Agricultural Extension } \\
\text { workers }\end{array}$} & \multicolumn{2}{c}{$\begin{array}{c}\text { Agricultural } \\
\text { Researchers }\end{array}$} & \multicolumn{2}{c}{ Total } \\
\hline Books & 30 & $17.4 \%$ & 5 & $8.9 \%$ & $\mathbf{3 5}$ & $\mathbf{1 5 . 3 \%}$ \\
Journals & 11 & $6.4 \%$ & 20 & $35.7 \%$ & $\mathbf{3 1}$ & $\mathbf{1 3 . 5 \%}$ \\
Newspapers & 15 & $8.7 \%$ & 10 & $17.9 \%$ & $\mathbf{2 5}$ & $\mathbf{1 1 \%}$ \\
Government publications & 15 & $8.7 \%$ & 13 & $23.2 \%$ & $\mathbf{2 8}$ & $\mathbf{1 2 . 3 \%}$ \\
Reference materials & 7 & $4.1 \%$ & 1 & $1.8 \%$ & $\mathbf{8}$ & $\mathbf{3 . 5} \%$ \\
Patents & - & - & 2 & $3.6 \%$ & $\mathbf{2}$ & $\mathbf{0 . 9} \%$ \\
Non-response & 94 & $54.7 \%$ & 5 & $8.9 \%$ & $\mathbf{9 9}$ & $\mathbf{4 3 . 4 \%}$ \\
\hline
\end{tabular}

Ninety-nine respondents (43.4\%) did not answer this question of which the majority (ninety-four; $54.7 \%$ ) were extension workers.

\subsection{Frequency of assistance from library staff}

Respondents were asked whether they sought any assistance from library staff when they visited libraries. The majority of respondents (seventy-three; 30\%) indicated that they sometimes seek assistance, representing forty-five extension workers $(26.1 \%)$ and twenty-eight researchers $(50 \%)$. Twenty-five $(11 \%)$ never seek assistance: ten $(5.8 \%)$ extension workers and fifteen $(26.8 \%)$ researchers. Twenty-three (10.1\%) respondents indicated that they often seek help, with seven (4.1\%) extension workers indicating that they "very often" seek help from library staff.

Library guides aid users by providing indications of where to locate different facilities within the library. These guides are available in all the libraries except at the Cotton Research Institute and Henderson's Laboratory section. 


\subsection{Finding material in the libraries}

The study also sought to establish whether respondents always find the information they are looking for in the library. This would provide an indication of the level of satisfaction among patrons. The majority of respondents (eighty-six; $37.7 \%$ ) indicated that they do not always find what they are looking for, representing forty-six (26.7\%) extension workers and forty $(71.4 \%)$ researchers. A total of forty-three $(18.8 \%)$ respondents answered that they find what they are looking for: thirtytwo extension workers (18.6\%) and eleven researchers (19.6\%).

\subsection{Interlibrary loan requests}

The interlibrary loan (ILL) service allows a library to request material on behalf of its patrons from another holding library when the material is not available from its own stock. This question intended to explore whether this service was available to the respondents in the study. The majority (ninety; $39.5 \%$ ) indicated that their libraries do not request material from other institutions, while thirty-nine (17.1\%) indicated that the service is provided.

\subsection{Database subscriptions and utilisation}

Not all libraries are connected to the internet, although access to subscriber databases is in some instances available from offices. The Central Library subscribes to The Essential Electronic Agricultural Library (TEEAL) database as well as the Global Online Access to Research in Agriculture (AGORA) initiative. While institutes are not subscribing to any databases, they have access to TEEAL through the Central Library.

\section{Discussion}

The number of extension workers without access to libraries and information centres, at $55 \%$, is a matter of concern and corroborates extension workers' failure to attend to farmers' information needs adequately, as indicated in the problem statement. Researchers have better access to libraries as libraries are found at research institutes, unlike extension workers who are mostly in the field with no suitable libraries at district, ward or village level. The introduction of rural information kiosks or telecentres could provide an alternative access to information. In their study in Bangladesh, Islam and Hasan (2009: 538) observe that knowledge and information centres and telecentres have been established in rural areas in order to provide information to marginalised and rural communities and to reduce technological discrimination and the digital divide between urban and rural areas. In addition to these centres, information kiosks, libraries and information centres have also been established to provide information in other sectors.

Mangstl, in Rhoe, Oboh and Shelton (2010: 2), posits that libraries support agricultural research by enhancing access to information through the effective management of resources and the provision of a wide range of information services and products to researchers, scientists, and policy makers in the agricultural sector. The lack of qualified librarians to staff libraries within the Ministry of Agriculture compromises the quality of service delivery. Opening hours, for example, are dependent on the availability of assigned researchers in research institutes. Qualified librarians apply their minds to professional duties like materials selection and processing, collection maintenance, and selective dissemination of information - important aspects in specialised libraries. These activities require time and resources and, from the study, it seems that they are not fully implemented. Although earlier studies by Aina (1991), Thapisa (1997) and Asopa and Beye (1997: 15) pointed to the perennial challenge of skilled library personnel, the Zimbabwean situation has since changed as library training is now offered in technical colleges and at universities as conventional courses as well as through distance education (National University Science and Technology [NUST] 2014, Zimbabwe Open University [ZOU] 2014).

Researchers and extension workers seek information for a variety of purposes, from general awareness to assisting colleagues within research and extension services. Extension workers are also involved in research and this confirms their rating of information sources in Table 3. It is important to note that both researchers and extension workers, in their majority, seek information to assist farmers. Hopefully, this translates to limiting those challenges to farmers that are articulated above. However, the library is not often used for this purpose as the majority of extension workers consult their departmental collections first (see Table 2), with a high preference for print sources. This demonstrates that extension workers generally have a propensity to use print sources. In contrast, the majority of researchers consult the internet first, with a high preference for electronic sources. The frequency of use and utilisation of library resources is therefore low among extension workers. Dulle (2000) made similar observations, finding that the use of libraries is very unpopular among extension workers. The preference for printed information is confirmed when publications are the most highlyrated organisation-based method of communicating information to farmers by extension workers. Visits to libraries are not frequent, the majority only visiting monthly - possibly because many do not find them useful. The other reason could be proximity from the workplace, particularly with extension workers.

Since researchers are usually based in institutions, they have greater access to the internet than extension workers who are highly mobile and may not have such access in the field, particularly at ward level. Noticeable contradictions were evident in the assertion by the majority of extension workers $(69.2 \%)$ that they can access the internet in the office compared to $23.2 \%$ of researchers. This implies that, while extension workers have relatively high access, they are not utilising the internet for information purposes, while researchers with limited access are maximising their use of this resource. However, an extension worker at ward level is more likely to find a mobile phone useful and not see the point of the internet in his or her work despite technological developments making it possible to access the internet on mobile phones. 
Dependence on print sources is therefore not the result of access or connectivity. Technical reports, books, professional meetings or workshops, fact sheets, and the internet are considered to be a very important source of information by the majority of researchers in this study. This finding corroborates observations by Gamage (2006: 20) that scientific information is communicated by scientists through scientific reports, research articles, papers presented at conferences, dialogues with colleagues, and through workshops. Gamage (2006) adds that the continued evolution of Information and Communications Technologies (ICTs) and the internet has also enhanced the availability of information in scientific disciplines. The internet provides access to the most current information, particularly research publications and online journals, explaining why the majority of researchers consider the internet and journals to be important. Majid, Anwar and Eisenschitz (2000) and Gamage (2006) observe that, besides the formal communication platforms described above, informal channels, like e-mail and conversations between colleagues, play a significant role in the communication of agricultural information. It can be deduced from this analysis that a variety of sources are consulted by the respondents when faced with an information need, and the preference for print or electronic sources is also influenced by connectivity.

Books are the most frequently consulted formal source, while face-to-face conversations, discussions, and consulting colleagues are the most frequently used informal communication channels. While the internet is regarded to be very important by researchers, it is nevertheless ignored by $31.6 \%$ of total respondents, as are theses and dissertations. The dependence on print sources is also confirmed when respondents indicated how they become aware of less recent books and journals, with the majority mentioning citations at the end of journal articles and citations at the end of book chapters. Respondents also utilise alternative sources of information, including circulars from the Ministry's head office, personal and departmental collections, media sources (newspapers, radio, audio materials), and other libraries. The FAO Regional Library, ICRISAT, and International Maize and Wheat Improvement Centre (CIMMIYT) libraries provide a wealth of alternative resources if the Ministry can provide access to these centres for researchers and extension workers. The University of Zimbabwe Library, being the legal depository centre for United Nations publications, could also be a useful alternative. Library cooperation is therefore important in this regard. Permission to use other libraries is usually restricted to the in-house use of materials and photocopying, hence the importance of facilitating inter-library loans which enable users to have access to materials for a longer period. This facility is not being fully utilised among Zimbabwean libraries.

The study revealed that information is communicated through a wide range of extension methods, tools and approaches, including manuals and other internal publications like factsheets, the mass media (radio and television), and through personal contact via on-farm demonstrations and field days. Prathap and Ponnusamy (2006) and Ani and Baba (2009: 18) concur, adding that mass media methods in agricultural information dissemination constitute methods of notifying farmers of new developments and emergencies, reaching a wider audience at a faster rate. It is imperative that such resources are harnessed for effective communication of agricultural information to rural communities through libraries, telecentres and other community gathering places.

Timeliness is an important aspect of scientific literature because of the changing nature of innovations. The same cannot be said of most materials in research institutes' libraries. Collections are mainly bound volumes of periodicals dating from the pre-1960s to the early 1980s in most instances, after which unbound journals appear. A similar trend is observed when one looks at the currency of books in these libraries. It is evident that the libraries have not been adequately funded as shown from the few purchases and incomplete collections of journals, evident when respondents were asked to indicate titles with which they are familiar in their subject areas. They suggested out-dated titles which have not been in print for some time. At the Central Library, there are some newer titles from 2003 and 2005 . The collections are dated, mainly due to budgetary constraints, although some current books and journal titles have been sourced via donations or exchanges. Budgets, where available, go towards subscriptions to newspapers, for example. Donations from the Technical Centre for Agriculture and Rural Development (CTA), such as Spore magazine, are on display in most libraries. Although the Central Library's strength is reflected in the availability of and access to databases, the inability of users to access these resources from other centres or institutes negates this advantage.

The libraries of the Ministry are generally not adequately equipped to support the information needs of researchers and extension workers. The library as an information resource is not rated highly by both categories of respondents. The resources are only concentrated in one locality. The respondents expressed dissatisfaction with the performance of the Ministry's information services as the quality of resources is poor. For example, the ILL service is low, with $40 \%$ of respondents indicating that their libraries do not provide this service; respondents indicated that they do not always find what they are looking for, even with the assistance of library staff; and awareness of less recent books and journals (see 5.2.5) makes no mention of current technology applications, but rather, a dependency on manual approaches. User education is important in creating awareness of services and facilities available to library clientele. Libraries must be commended for the library guides that are available in all the libraries but one. The lack of confidence in library services stems from the libraries' inability to enforce their status as information providers within the different institutions surveyed. Studies by Dulle et al. (2001) and Rhoe, Oboh and Shelton (2010) revealed similar challenges facing libraries in meeting agricultural information needs, emanating mostly from poor funding which affects their capacities to expand.

\section{Conclusion and recommendations}

The information seeking pattern of the respondents in this study was largely determined by the information sources and their availability in terms of proximity and format. The study concluded that a larger number of researchers have access to a library or information resource centre in their work environment or community than extension workers do, hence the reliance on departmental collections and circulars by the latter group. Lack of information hampers the capacity of extension workers. Manuals and handbooks should thus be updated and made available to extension workers. The 
Herald ("Ministry equips extension officers" 2011), for example, reported that every extension worker was going to be given a farm management handbook for use. The exponential growth of the number of farmers since the beginning of the land distribution programme in 2000 further exacerbates the challenges facing research and extension systems. Some are first-time farmers while others have migrated into commercial farming and have encountered new crops such as soya beans, tobacco and livestock production. Hence, they need knowledge in these areas, making the demand for information among researchers and extension workers even higher.

The internet is also favoured by researchers and, because of the poor quality of services and resources, libraries are not preferred as the first point of call when seeking information. The study also showed that the Central Library has access to databases which provide greater opportunity to access journal articles; however this resource is underutilised due to a lack of qualified library personnel, awareness and inadequate resources at the research institutes and AGRITEX centres. Funding remains a major challenge that affects the performance of research and extension institutions and the provision of information resources.

Faced with these challenges, and in order to maximise access, the study therefore recommends the following:

- that adequate funding be availed to libraries so that they can improve the quality of resources;

- that the ministry upgrades ICT access at research institutes and at provincial and district extension centres so as to maximise access to databases like TEEAL and AGORA, and the growing literature available through open access initiatives;

- that institutes should send their information requests to the Central Library, which will in turn conduct searches and send the retrieved information electronically or as hard copies;

- that professionally qualified library personnel be hired so that they can improve the quality of services through developing Selective Dissemination of Information (SDI) profiles for the research institutes to which they would send contents pages from databases on a regular basis;

- that, due to their limited access to libraries, extension workers should utilise libraries at research stations and other institutions in their districts, while at the same time the Ministry of Agriculture must strengthen library resources at district centres;

- that the Central Library renews cooperation with other libraries in Zimbabwe at ILL level in order to supplement its collection and those of research institutes' libraries; and,

- that the libraries take advantage of CTA and other institutions like the World Bank's annual call for assistance.

Empowering both researchers and extension workers with adequate information resources will translate to increased production by farmers, contributing significantly to the Millennium Development Goals (MDGs) on poverty reduction amongst developing economies.

\section{References}

Aina, L.O. 1991. Information for successful agriculture. World Libraries, 2:1. [Online]. http://www.worlib.org/vol102no1/print/aina_print.html (12 May 2014).

Ani, A.O. and Baba, S.A. 2009. Utilization of selected electronic mass media as sources of agricultural information by farmers in northern Taraba state, Nigeria. Tropical Agricultural Research and Extension, 12(1): 17-22. [Online]. http://www.sljol.info/index.php/TARE/article/viewFile/1979/1636 (15 May 2014).

Arex battles to fill 6600 posts, service delivery compromised. 2006. Herald. 14 March: 6.

Asopa, V.N. and Beye, G. 1997. Management of agricultural research: a training manual. V. 8.Rome: FAO.

Chema, S., Gilbert, E. and Roseboom, J. 2003. A review of key issues and recent experiences in reforming agricultural research in Africa. London: International Service for National Agricultural Research (ISNAR).

Dulle, F.W. 2000. The extension triad approach in disseminating agricultural information to extension workers: some experiences from the Southern Highlands Dairy Development Project, Tanzania. Journal of Information Science , 26(2): 121-128.

Dulle, F.W., Lwehabura, M.J.F., Mulimila, R.T. and Matovelo, D.S. 2001. Researchers'perspectives on agricultural libraries as information sources in Tanzania. Library Review, 50(4):187-192.

Farmers struggle to access extension services. 2006. Herald. 27 November: 2.

Food and Agriculture Organization of the United Nations (FAO). 2000. Improving access to agricultural information: $1^{\text {st }}$ Consultation on Agricultural Information Management. Working Document. [Online]. http://www.fao.org/docrep/meeting/X7035E.htm (04 June 2013).

Gamage, C. 2006. Information needs and information seeking behaviour of environmental scientists in universities in Sri Lanka: major issues and concerns. Journal of the University Librarians of Sri Lanka, 10:19-28. [Online]. http://www.sljol.info/index.php/JULA/article/view/315 (04 June 2014).

Global Finance . 2013. Zimbabwe country report. [Online].http://www.gfmag.com/gdp-data-country-reports/143zimbabwe-gd country-report.html\#axzz329eiCh2J (19 May 2014).

Islam, M.S. and Hasan, M.N. 2009. Multipurpose community telecentres in Bangladesh: problems and prospects. The Electronic Library, 27(3):537-553.

Kiplang'at, J. 1999. An analysis of the opportunities for information technology in improving access, transfer and the use of agricultural information in the rural areas of Kenya. Library Management, 20:115-127. 
Kiplang'at, J. 2004. Diffusion of information and communication technologies in communication of agricultural information among agricultural researchers and extension workers in Kenya. PhD thesis. University of Zululand.

Majid, S., Anwar M.A. and Eisenschitz, T.S. 2000. Information needs and information seeking behaviour of agricultural scientists in Malaysia. Library and Information Science Research, 22(2):145-163.

Ministry equips extension officers. 2011. Herald. 18 March: B2

Moyo, S., Moyo, Y. and Matondi, P. 2004. Land reform policies in Zimbabwe. In Land reform and tenure in southern Africa: current practices, alternatives and prospects. M. Munyuki-Hungwe, Ed. Harare: Documentation Unit, University of Zimbabwe. 153-168.

Muir-Leresche, K. 2006. Agriculture in Zimbabwe. In Zimbabwe's agricultural revolution revisited. M. Rukuni, P. Tawonezvi, C. Eicher, M. Munyuki-Hungwe and P. Matondi, Eds. Harare: University of Zimbabwe Publications. 99118.

National University Science and Technology (NUST). 2014. Library and Information Science. [Online]. https://www.nust.ac.zw/index.php?option=com_content\&view=article\&id=122\&ltemid=362 (19 May 2014).

Pazvakavambwa, S.C. and Hakutangwi, M.B.K. 2006. Agriculture extension. In Zimbabwe's agricultural revolution revisited. M. Rukuni, P. Tawonezvi, C. Eicher, M. Munyuki-Hungwe and P. Matondi, Eds. Harare: University of Zimbabwe Publications. 217-234.

Prathap, D.P. and Ponnusamy, K.A. 2006. Effectiveness of four mass media channels on the knowledge gain of rural women. Journal of International Agricultural and Extension Education, 13:1 [Online]. https://www.aiaee.org/attachments/149_Prathap-Vol-13.1-8.pdf (10 April 2014).

Rees, D., Momanyi, M., Wekundah, J., Ndungu, F., Odondi, J., Oyure, A.O., Andima, D., Kamau, M. et al. 2000. Agricultural knowledge and information systems in Kenya: implications for technology dissemination and development. Agricultural Research and Extension Network Paper 107. London: Department for International Development.

Rhoe, V., Oboh, V. and Shelton, P. 2010. The role of libraries in supporting agricultural policy research: evidence from selected university and research institute libraries in Nigeria. Abuja: IFPRI. [Online].http://www.ifpri.org/sites/default/files/publications/nsspbp14.pdf (02 December 2013).

Thapisa, A.P.N. 1997. A quest for an agricultural information programme for Southern Africa. Library Management, 18(4): 196-204.

Zimbabwe Open University. 2014. Department of Information Science and Records Management.[Online]. http://www.zou.ac.zw/faculties/faculty_of_applied_social_science/depart_of_information_science_and_records_mana gement.html (19 May 2014). 